\title{
Development of Higher Order Thinking Skills-Based Assessment Instrument for Learning Review Text in Senior High School
}

\author{
Zira Fatmaira \\ Indonesian Language Education and Literature \\ State University of Medan \\ Medan, Indonesia \\ Corresponding email: zirafatmaira0301@gmail.com
}

\author{
Syahnan Daulay \\ Indonesian Language Education and Literature \\ State University of Medan \\ Medan, Indonesia
}

\author{
Abdurahman Adisaputera \\ Indonesian Language Education and Literature \\ State University of Medan \\ Medan, Indonesia
}

\begin{abstract}
This study aims to develop a higher order thinking skills (HOTS) assessment instrument for learning text review in students class XI of state senior high school 5 Binjai. This type of research is research and development that refers to the development model of Borg And Gall. The development model of Borg And Gall with the stages of (1) Research and information collecting, (2) Planning (3) Develop preliminary form of product (4) Preliminary field testing (5) Main product revision (6) Main field testing (7) Operational product revision (8) Operational field testing (9) Final product revision (final product revision). The results of this study indicate that: (1) Validation of material experts on the assessment of content eligibility on average was vin ery good criteria $(\mathbf{8 4 . 3 8 \%})$, the presentation feasibility of the average is very good criteria $(\mathbf{8 5 . 5 8 \%})$ and language feasibility The average criteria was very good $(84.62 \%)$. In addition, evaluation expert validation on multiple choice instrument validation assessments was on very good criteria $(92.11 \%)$, on average the instrument validation assessment was in very good criteria $(92.31 \%)$. The practicality of the assessment instrument was concluded based on the teacher's response and student response; (i) Student responses to HOTS-based assessment instruments in the field trial of $86 \%$ of students stated that HOTS-based assessment instruments was practical, (ii) the teacher's response to HOTS-based assessment instruments in the field trial was $82 \%$ included in the practical category. Similarly, the influence of the use of HOTS-based assessment instruments on the ability to higher order thinking skills of students in the average/moderate category $\mathbf{( 4 0 . 2 9 )}$ because $40<x$ total score .60 . Thus, it can be concluded that the instrument for assessing higher order thinking skills at State High School 5 Binjai is of sufficient qualityp.
\end{abstract}

Keywords--assessment instrument; higher order thinking skills; Indonesian Language

\section{INTRODUCTION}

Educational Assessment according to Permendiknas No. 23 Year 2016 concerning Educational Assessment Standards is the process of gathering and processing information to measure the achievement of learning outcomes of students [1]. Assessment is not just data collection of students, but also processing to obtain an overview of the learning process and results of students. Walle (in Budiman and Jailani, 2014) stated that principles and assessment standards emphasize two main ideas, namely assessment must improve student learning and assessment is a valuable tool for making teaching decisions [2].

Assessment is an activity which is very important in learning Indonesian language. Assessment can find difficulties in learning and the possibility to develop achievement of students as a tool of diagnosis that supports teachers to determine whether a student needs to join remedial or even enrichment program. In addition, assessment is also an effort of educators to be able to find weaknesses and shortcomings of the learning process that has been done (Uno \& Koni, 2014) [3]. Therefore the position of the assessment instrument for learning outcomes is very strategic in the decision making of teachers and schools related to the achievement of learning outcomes of students, including higher order thinking skills (HOTS). Brookhart's high-level thinking category (2010) covers several aspects, namely: 1) Analysis, evaluation, creation, 2) Logical reasoning or logical reasoning, 3) Decision and critical thinking, 4) Solution problems, 5) Creativity and creative thinking [4].

Assessment instruments contribute significantly in the learning process. This is also inseparable from teacher and student learning activities in the classroom. Through the application of several learning models in the classroom can be an opportunity for teachers to apply learning activities at the level of HOTS. In the preparation of assessment instruments, teachers should design tests in collaborative learning to train collaboration skills, communication skills, ability to argue and the ability to control emotions. The teacher is also expected to 
be able to compile HOTS-based questions so that students can solve test questions at $\mathrm{C} 4$ to $\mathrm{C} 6$ levels.

Based on the description above, the problem faced by teachers is the teacher's ability to develop HOTS assessment instruments is still lacking, in addition to the unavailability of assessment instruments specifically designed to train HOTS or higher order thinking skills of students. Students who have HOTS if they are not given the opportunity to develop and are not directed then their abilities do not develop.

Based on pre survey analysis of needs in a form of questionnaire on assessment instruments proposed to 5 teachers in State High School 5 Binjai revealed that $80 \%$ teachers stated that they knew very much of assessment instruments and $80 \%$ knew to the steps of organizing assessment instruments. However, only $40 \%$ teachers who tried the assessment instruments before use and 40\% knew how to develop assessment instruments thus in total of $80 \%$ teachers needed valid, effective and practical assessment instruments. The pre-survey acquisition needs to be observed in the future by conducting reformation so that the acquisition of HOTS can be increased again.

Development of test questions assessment instrument on text review material based HOTS is needed to measure the level of students' ability to increase knowledge in the material of the review text. Dalman (2014) stated that a review is a term used to judge whether a book is good or not. Review is an assessment to a literary work of an author that can be commented on from the results of the writing read by the reviewer [5].The development of this assessment instrument is also very needed in supporting the progress of student learning outcomes in the review text material.

Based on the above problems, the researcher was interested in conducting research on the development of HOTS-based review text assessment instruments produced according to the needs of teachers and students in school.

The objective of this research is to describe the development of assessment instrument of review text based on HOTS, to describe the feasibility of assessment instrument of review text based on HOTS, and to describe the ability to understand review text writing questions based on HOTS to students.

\section{METHOD}

The type of this research is Reseasrch and Deveplomend. According to Gay (1990) development research is an attempt to develop a product that is effective for school use, and not to test a theory [6]. Subjects in this study were 3students class XI of State High School 5 Binjai amounting to 36 students. As well as 3 validation experts with criteria for material experts, construction experts and linguistics / Indonesian language experts. The research was carried out at State Senior High School 5 Binjai. The researcher used the Borg and Gall development research model which included 10 general steps namely research and information collecting, planning, develop preliminary form of product, preliminary field testing, main product revision, main field testing, operational product revision, operational field testing, final product revision, dissemination and implementation (Borg \& Gall, 2003) [7]. This research instrument was a validation sheet, test, and student response questionnaire. The analysis technique used was the analysis of the results of expert validation (validator), the analysis of items by examining the validity of the questions empirically includes the validity of test items, reliability, level of difficulty, differentiation.

\section{RESULTS AND DISCUSSION}

\section{A. The Process of Developing HOTS-Based Assessment Instruments}

The first stage carried out in this study was to conduct a preliminary study which began with a needs analysis. every learning product which will be developed must be adjusted with the users' needs (students and teachers), as researched by Anwar, Daulay, and Hadi (2018) that the first stage to carry out in the process of learning product development starts from analysis of needs [8]. Based on the results of the analysis of teacher needs of HOTS-based assessment instruments, $80 \%$ of teachers need valid, effective and practical assessment instruments and students' needs for HOTS-based assessment instruments also vary because the knowledge of Indonesian students varies. The second stage, designing and designing assessment instruments that will be developed based on data that has been obtained from the initial stage. The third stage, validating teaching materials that have been developed to material experts and evaluation experts to obtain validity of assessment instruments.

The fourth stage, the assessment instrument that has been validated, then revised based on the results obtained from the material experts and evaluation experts. then, validated the Indonesian language teacher to obtain an Indonesian teacher's response to the HOTS-based assessment instrument that had been developed. The fifth stage, conducts individual trials of assessment instruments to students to find out students' responses to assessment instruments that have been developed. The sixth stage, after obtaining the results of the individual trials, the assessment instrument revised in accordance with the results obtained, if it receives a good response, the next stage can be carried out. In the seventh stage, conducting a limited group trial with 9 students. At this stage, because there were no improvement suggestions from students, then proceed to the next stage. In the eighth stage, conduct a limited group trial with a total of 35 students.

\section{B. Feasibility of HOTS-Based Assessment Instruments}

Based on the results of material experts assessment in the aspect of content feasibility then obtained a total score of 108 with the percentage of $84,38 \%$ and categorized as very valid, this means that the aspect of content feasibility did not need revision. In the aspect of delivery feasibility obtained a total score of 89 with a percentage of $85,58 \%$ or categorized as very valid. In the aspect of language feasibility obtained a score of 88 with a percentage of $84,62 \%$ and categorized as 
very valid which means the assessment instruments based on HOTS did not need revision.

Based on the evaluation results of evaluation experts on multiple choice questions, the total score was 140 with a percentage of $92.11 \%$ and in a very valid qualification, this means that multiple choice questions did not need to be revised. In the description problem obtained a score of 96 with a percentage of $92.31 \%$ or in a very valid qualification which means that HOTS-based assessment instruments did not need to be revised.

Based on the results of the teacher's assessment of the assessment instrument, the score was 49 with a percentage of $82 \%$ and was in a very valid qualification, this means that multiple choice questions did not need revision.

The average percentage of assessment results in individual trials of HOTS-based assessment instruments was $80.6 \%$. The average percentage of assessment results in small group trials on HOTS-based assessment instruments was $81.3 \%$. Based on the results of the assessment on the material of review text, the individual trials and small group tests did not improve.

Field trials involving 35 students obtained a percentage of $86 \%$, that is, the percentage included in the excellent category. Sinaga (2007) stated that to determine the achievement of learning objectives in terms of student responses, if the number of students who give a positive response is greater or equal to $80 \%$ of the number of subjects studied for each trial. Therefore the assessment instruments developed is considered very good [9].

The suggestions and the results of the trial on prototype II were then revised. The results of the revision (prototype III) were tested on the research trial subjects, namely students of class XI of State High School Binjai. Class XI contained 35 students. The results obtained from the work of students class XI of State High School Binjai were analyzed to measure or know the level of students' higher order thinking skills. In addition to analyzing the validity of the contents of the questions, reliability test, level of difficulty and differentiation of instruments developed, in this stage also revised the instruments that were tested so as to produce an appropriate product.

Based on the results of HOTS-based assessment instrument, the average level of validity of multiple choice questions was 0.46 and description was 0.638 in activity 1 . In activity 2 , the average level of validity of multiple choice questions was 0.46 and description was 0.552 .

Assessment instrument to measure students' higher order thinking skills was reliable in multiple choice questions with a value of 0.646 with very high interpretation and a description of 0.62 with high interpretation in activity 1 . In activity 2 the reliability level of multiple choice questions was 0.4 with medium/sufficient interpretation and a description of 0.495 with medium interpretation.

Based on the results of the analysis of the items in terms of the level of difficulty of the instrument of assessment of higher order thinking skills in activity 1 it was known that from 15 multiple choice questions all were in the medium category with an average difficulty level of 0.626 and from 5 questions described there were 2 questions with moderate category, and 3 questions with difficult category with an average level of difficulty of 0.398 in the medium category. In activity 2 it was known that out of 10 multiple choice questions all were in the medium category with an average level of difficulty of 0.623 and of the 5 questions that were tested there were 4 questions in the medium category, and 1 problem with difficult category with an average difficulty level of 0.444 in medium category.

In Activity 1, it was found that out of 15 questions tested there were no very bad items, the average score of the instrument was 0.36 with a moderate / sufficient category. In activity 2, it was known that out of 10 questions tested there was 1 item with good category, and 9 items with very good category with the results of the average difference between 0.80 instruments with a very good category.

Based on the analysis of content validity at the level of validity, reliability and level of difficulty the problem can be used but in different power tests there were some questions that were not feasible to use, namely in activity 1 multiple choice questions number 2 and description questions in numbers 2 and 4 in activity 2 .

\section{Students' Ability to Understand HOTS Questions}

Based on the data analysis to measure the students' higher order thinking skills, it was known that out of 35 students in the trial assessment instrument, there were no students with higher order thinking skills in the trial results, with sufficient/moderate category, there were 16 students $(0.457$ $\%$ ) included in the category of having higher order thinking skills in the moderate/ sufficient category, 19 students $(0.543 \%)$ included in the category of having higher order thinking skills in less category. Thus the average higher order thinking skills of students was $40.829 \%$ with sufficient category.

\section{CONCLUSION}

Based on the results of research and previous discussion, then it can be concluded that:

1. The process of developing HOTS-based assessment instruments on Indonesian language subjects at State High School 5 Binjai through 9 stages, namely; (1) Research and information collecting, (2) Planning (3) Develop preliminary form of product (4) Preliminary field testing (5) Main product revision (6) Main field testing (7) Operational product revision (8) Operational field testing (9) Final product revision (final product revision)

2. The level of feasibility of HOTS-based assessment instruments based on the results of this study shows:

(a) the validation of material experts on the assessment of the feasibility of content is in a very valid criteria with an average value of $84.38 \%$. The feasibility of delivery is very valid with an average value of $85.58 \%$ and the feasibility of the language is very valid with an average value of $84.62 \%$, (b) evaluation expert validation on multiple choice instrument validation assessment is very valid with an 
average value of $92.11 \%$ and in the instrument validation assessment of description is in very valid criteria with an average value of $92.31 \%$, and (c) the results of the questionnaire responses of teachers to the assessment tool based on higher order thinking skills (HOTS) according to the teacher is averaged $82 \%$ in very practical category with a student response rate of $86 \%$ in a very practical category.

3. The ability of students to understand the problems of higher order thinking skills (HOTS) on average in the moderate/ sufficient category $(40,829)$ thus it can be stated that the instrument for evaluating higher order thinking skills in State High School 5 Binjai students with moderate/sufficient quality.

\section{REFERENCES}

[1] Permendiknas No. 23 Tahun 2016, Standar Penilaian Pendidikan: Jakarta.

[2] Budiman, A. and Jailani, "Pengembangan Instrumen Asesmen Higher Order Thinking Skill (HOTS) pada Mata Pelajaran Matematika SMP Kelas VIII Semester 1”. Jurnal Riset Pendidikan Matematika, vol. 1, pp. 140, 2014.

[3] Uno. B. H. and Koni, S., Assessment Pembelajaran: Jakarta. Bumi Aksara, 2014, pp. 5-6.

[4] Brookhart, S. M., How to Assess High-er Order Thinking Skills in Your Class-room. Alexandria: ASCD, 2010, pp. 14-15.

[5] Dalman, Keterampilan Menulis. Jakarta : PT Raja Grafindo Persada, 2014, pp. 229.

[6] Gay, L.R., Educational Evaluation And Measurement Competencies For Analysis And Application. New york: Macmilan Publishing Compan, 1990.

[7] Borg R.W. dan Gall M. D. Educational Research; An Intruction, Eight Edition: Longman, 2003, pp. 775.

[8] Anwar, W., Syahnan D., and Wisman H., "Development of Procedural Text Materials Based on Traditional Marriage Ceremony of Malay For Students Class XI SMA Negeri 1 Medang Deras District of Batubara". International Journal of Education, Learning and Development, vol. 6, pp. 14-24, April 2018.

[9] Sinaga, B., Pengembangan model pembelajaran matematika berdasarkan masalah berbasis budaya batak (PBMB3). Disertasi. Surabaya: Program Pascasarjana UNESA, 2007. 